\title{
Reproductive biology, oogenesis and early development in the brood-caring sea anemone Actinostola spetsbergensis (Anthozoa: Actiniaria)
}

\author{
K. RIEMANN-ZÜRNECK* \\ Institut für Meeresforschung; Bremerhaven, \\ and \\ Biologische Anstalt Helgoland; \\ Hamburg 50, Federal Republic of Germany
}

KURZFASSUNG: Fortpflanzungsbiologie, Oogenese und frühe Larvalentwicklung der brutpflegenden Aktinie Actinostola spetsbergensis (Anthozoa: Actiniaria). Während der Fortpflan-

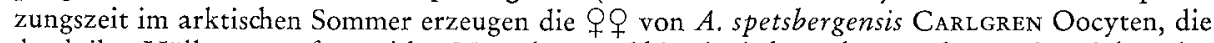
durch ihre Hülle aus umfangreicher Mesogloea und histologisch stark verändertem Ovarial-Endoderm auffallen; die Anzahl der sich pro Weibchen entwickelnden Eier ist ungewöhnlich gering. Das befruchtete Ei löst sich aus dem Ovar, verläßt jedoch das Muttertier nicht, sondern wird mit Hilfe seiner nichtzelligen Hülle im oberen Teil des Körpers befestigt. Dort verläuft die Embryonal- und Larvalentwicklung bis zu fortgeschrittenen Larvenstadien (meist bis zum 24-Septen-Stadium). Die Furchung ist eine modifizierte Superfizialfurchung, das Endoderm scheint durch eine Kombination von Invagination und polarer Immigration zu entstehen. Im Gegensatz zu anderen brutpflegenden Aktinien besitzt A. spetsbergensis besondere Einrichtungen, die der Brutpflege dienen, wobei die Fürsorge für die Nachkommen schon während der Oogenese beginnt. Dic ökonomische Eiproduktion in Verbindung mit einer hochspezialisierten Brutpflege läßSt A. spetsbergensis besonders gut an die ökologischen Bedingungen arktischer Lebensräume angepaßt erscheinen.

\section{INTRODUCTION}

The females of the Arctic sea anemone Actinostola spetsbergensis Carlgren shelter their offspring up to late developmental stages inside their gastrovascular cavities (RIEMANN-ZüRNECK, 1976a). Internal brood-caring is a common feature in other polar distributed anemones, whereby the sheltered juveniles occur in all stages between egg, Edwardsia-stage and small anemones. In contrast to the development via planktonic larvae the development of these viviparous species is relatively direct by avoiding particular larval differentiations.

However, in Actinostola spetsbergensis the juveniles in the gastral cavity differ in more than one respect from all stages that might be expected in a brooding anemone:

\footnotetext{
* Member of the "Taxonomische Arbeitsgruppe" at the Biologische Anstalt Helgoland.
} 
they are spherical transparent bodies of different size and structure, representing a series of different developmental stages ("giant larvae": RIEMANN-ZỦRNECK, 1976a; see Fig. 1).

The interesting spherical larvae inside the females are not a peculiarity restricted to the reproduction of $A$. spetsbergensis, but they have a free-living larval type equivalent, which have been often reported since VAN BENEDEN (1898) and have been collected pelagically in open ocean regions, most abundantly in considerable depths. Up to now no adult species of sea anemone has been recognized which can be linked with these enigmatic giant larvae, although anatomical investigations (mainly by CARLGREN, 1924, 1934) have revealed that the giant larvae are more widely distributed among the Actiniaria than may be expected. The distributional pattern of the pelagic giant larvae and the fact that littoral and sublittoral actinians have a different larval type indicate that the pelagic giant larvae probably represent the larvae of deep-sea actinians. These large lecithotrophic larvae with presumably long pelagic life may achieve wide dispersal in deep-sea habitats.

In $A$. spetsbergensis the spherical giant larvae are kept inside the maternal animal, but they retain the developmental pattern of the pelagic giant larvae. Thus, A. spetsbergensis is the first adult anemone which is known to produce giant larvae; the reproductive peculiarities of this species may serve as a model to elucidate the ontogenetic origin and fate of the still enigmatic pelagic larvae.

Morphological and ecological aspects of the later stages of the ontogenesis of A. spetsbergensis have been discussed elsewhere (RIEMAnN-Zürneck, 1976a). The present paper is intended to supplement our knowledge of the reproductive cycle of this species, including a description of the early ontogenetic stages and a discussion of some striking deviations in the reproductive biology.

\section{MATERIAL AND METHODS}

The animals originate from different Atlantic and Pacific localities (RrEmannZürNECK, 1976a; Table 1). In addition to my earlier paper, three males and five females were included in the investigation of gametogenesis.

Sections were carried out after paraffin-embedding 7 to 10 microns thick and stained with a slightly modified "Azan" triple staining.

\section{RESULTS}

\section{Breeding period and formation of gonads}

A. spetsbergensis reproduces sexually during the arctic summer; the formation of gonads in the investigated animals seems to be dependent on temperatures occurring in the natural environment: most of the animals show formation of gonads at the beginning of June, whereas females from the Canadian arctic region $\left(64^{\circ} 24^{\prime} \mathrm{N}\right.$ $77^{\circ} 56^{\prime} \mathrm{W}$ ) possess visible oocytes only in late July. 
The formation and appearance of testicles corresponds with other Actinostola species. By contrast, the ovarial follicles and the oocytes appear rather uncommon. Particularly conspicuous is the extremely low number of oocytes: in small females only a few oocytes are present and even in large animals the number of developing oocytes never exceeds 100. In the North East Atlantic animals the first period of oocyte formation is followed by a second one approximately one month later, so a single female may contain mature eggs and giant larvae at the same time in July and August. Thus, the breeding period in East Atlantic animals extends from the beginning of June until lateSeptember according to the presence of oocytes and larvae in females.

In a few females some mature eggs are still present inside the ovarial follicles in September. The histological appearance of these eggs suggests, however, that they are about to be resorbed.

\section{Oogenesis}

The smallest oocyte observed measures 30 microns in diameter (Fig. 1A) and is enclosed in a pouch of mesogloea opening towards the septal epithelium. The oocyte stretches in the direction of the opening by forming a small process. Compared with the epithelium at a certain distance, the epithelium around the oocyte shows slight histological alterations: Narrow, high cells with distinct nuclei are visible, forming a somewhat thicker layer around the oocyte. The germ vesicle (nucleus) does not appear until the oocyte reaches the size of about 100 microns; it is excentrically located in such a manner that it approaches the point where the oocyte seems to be in contact with the septal epithelium (Fig. 1C). Oogenesis proceeds in enlargement of both oocyte and envelope, thus achieving the characteristic shape and structure of the A. spetsbergensis egg, which may be recognized even with the naked eye (Fig. 1C-1E). The narrow cells of the envelope have changed into ciliary cells, resembling those of the ciliated tracts in mesenteric filaments or in siphonoglyphs. Between the peripheral parts of the ciliary cells there are additional grape-like cells. The development of this histological picture is accompanied by alterations in the structure and appearance of the mesogloea around the oocyte: it is thickened and the fibrils show a spongy arrangement. In the East Atlantic specimens there is a further thickening of the mesogloea just over the germ vesicle, whereas Canadian and Pacific animals show a more common picture by a weakened spot of mesogloea in this particular region (Fig. 2): the mesogloea is thin or may even be interrupted in this area. The ciliary epithelium opposite the germ vesicle is always reduced to a thin layer, which seems to be almost filled up with nuclei (Fig. 1C-1E).

Grains of yolk are first observed, when the oocyte reaches the diameter of about 250 microns. They appear near the germ vesicle and near the periphery of the oocyte (Fig. 1C), growing out to small darkly stainable spheres. After enlarging and multiplying, these yolk balls spread all over the cytoplasm and change into larger yolk isles (diameter about 30 microns), composed of two components with different staining reactions (Fig. 1D).

Alterations of the nucleus do not take place until the oocyte has reached its final size. During early oogenesis the nucleolus shows acidophilic reaction with azocarmine. 

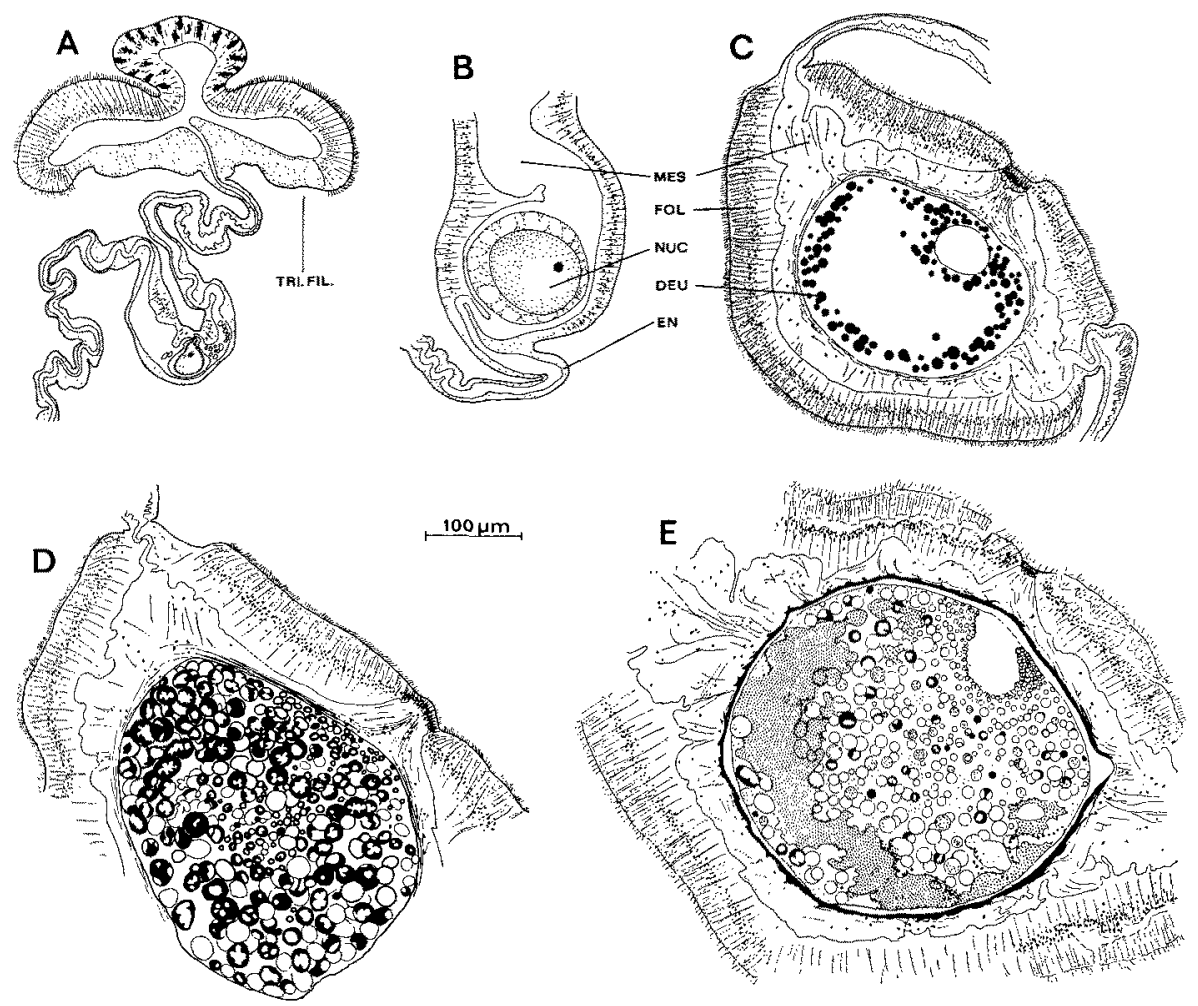

Fig. 1: Oogenesis in Actinostola spetsbergensis. A Smallest oocyte. B Oocyte showing mucleus and first histological alterations of endoderm, $C$ Oocyte with typical structure of ovarial envelope during yolk formation. D Oocyte with yolk isles, composed of two different components. $E$ Mature egg with typical yolk arrangement, disappearing nucleus and dissolving ovarial endoderm. DEU $=$ deutoplasm (yolk), $\mathrm{EN}=$ endoderm, FOL $=$ follicle, $\mathrm{MES}=$ mesogloea, NUC = nucleus, TRT.FIL. = trilobate mesenteric filament
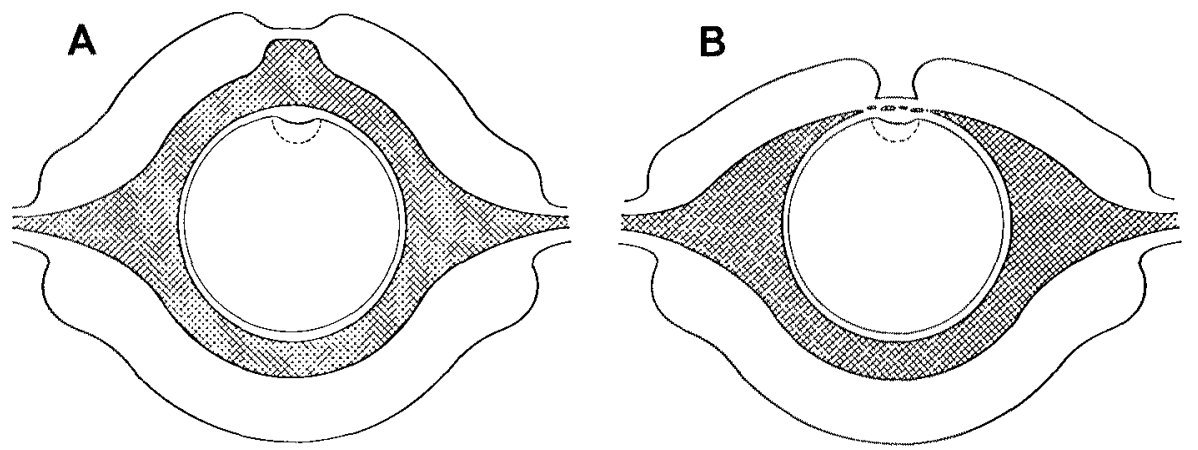

Fig. 2: Different structure of ovarial-mesogloea in Actinostola spetsbergensis from different localities. $A$ East Atlantic specimens. $B$ Canadian and Pacific specimens 
During maturation the nucleolus and the distinct line between germ vesicle and cytoplasm disappear (Fig. 1E). The germ vesicle takes a pink stain now and is surrounded by a foamy substance, which extends into the cytoplasm. Alterations of the nucleus and of the nucleic membrane occur together with other maturation processes of the yolk and of the ovarial epithelium.

The mature egg of $A$. spetsbergensis varies in size between 400 und $750 \mu \mathrm{m}$ (compare the egg of Ceriantbus lloydii as described by Nyнolm, 1943, p. 106: 190 to $310 \mu \mathrm{m}$ ). The ovarial epithelium shows signs of dissolution (Fig. 1E) in detaching the peripheral ciliated part including the grape-like cells, leaving behind the lower part with the nuclei. The yolk content of the oocyte has separated into a peripheral homogeneous layer (approximately 100 microns thick) and a central mass of larger yolk particles (Fig. 1E).

\section{Embryonic non-cellularenvelope}

The detached, fertilized eggs are enclosed in a peculiar non-cellular envelope (Fig. 4,5 ); this special pellicle might be produced during leaving the ovarium or past fertilization, but it might be also the remainder of the ovarial epithelium after the described dissolution processes. From the investigated material it is impossible to decide on the origin of this envelope, but the non-cellular envelope plays an important part in the reproductive biology of $A$. spetsbergensis: the early developmental stages are fixed in the upper part of their mother's interior by means of this envelope,
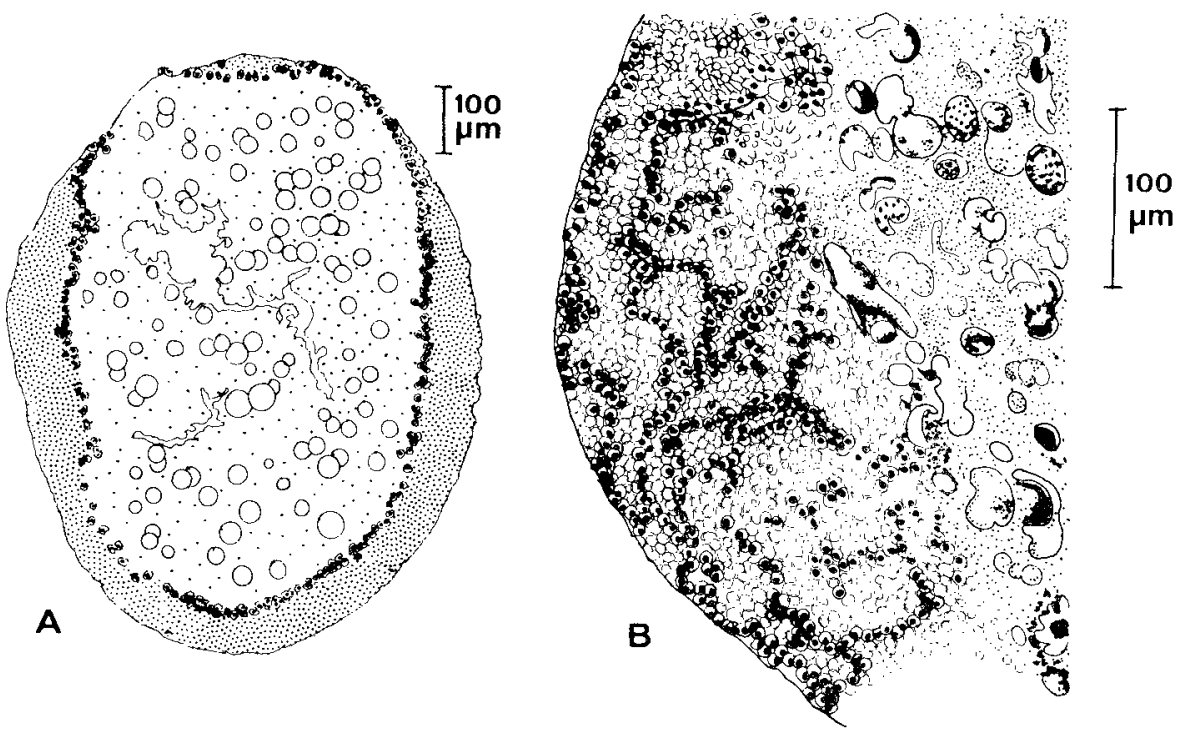

Fig. 3: Cleavage and endoderm formation in Actinostola spetsbergensis (embryonic envelope omitted). A Blastula stage showing blastoderm cells below the germ surface on the boundary between homogeneous and heterogeneous yolk area. B Polar cap of blastoderm cells during endoderm formation 


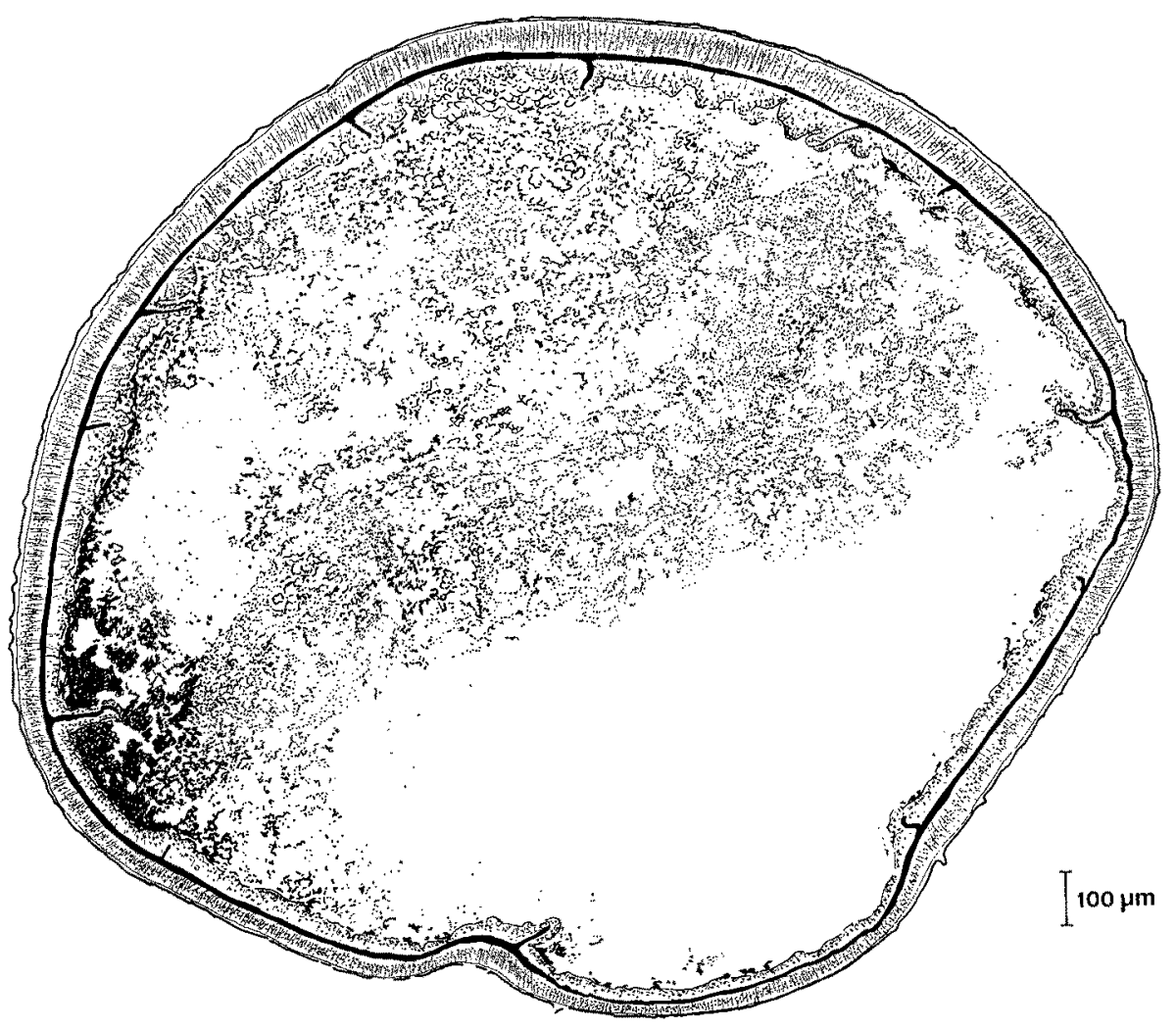

Fig. 4: Smallest larval stage observed in Actinostola spetsbergensis with $8+4$ septa and yolk residues. Note the noncellular embryonic envelope

which possesses probably adhering capabilities. This is the reason why small developmental stages are never found freely in the gastral cavity; they are hidden between the septal filaments not far from the gonads. There, all developmental stages from fertilized eggs until larvae with 24 septa are found (Fig. 5). This particular manner of taking care for the early embryonic stages is the most striking feature in the brooding habits of $A$. spetsbergensis and, moreover, it is a novelty in brooding anemones as a whole.

\section{Cleavage and formation of endoderm}

Cleavage should be described as superficial, but in a quite different manner from that of other yolky eggs of Coelenterata (SIEWING, 1969; p. 48; NYHOLM, 1943; p. 114: Cerianthus lloydit). Instead of arranging alongside the surface of the germ, the cleavage cells appear on the boundary between homogeneous and heterogeneous yolk substances (at some distance below the germ surface, Fig. 3A) as a loose formation of 


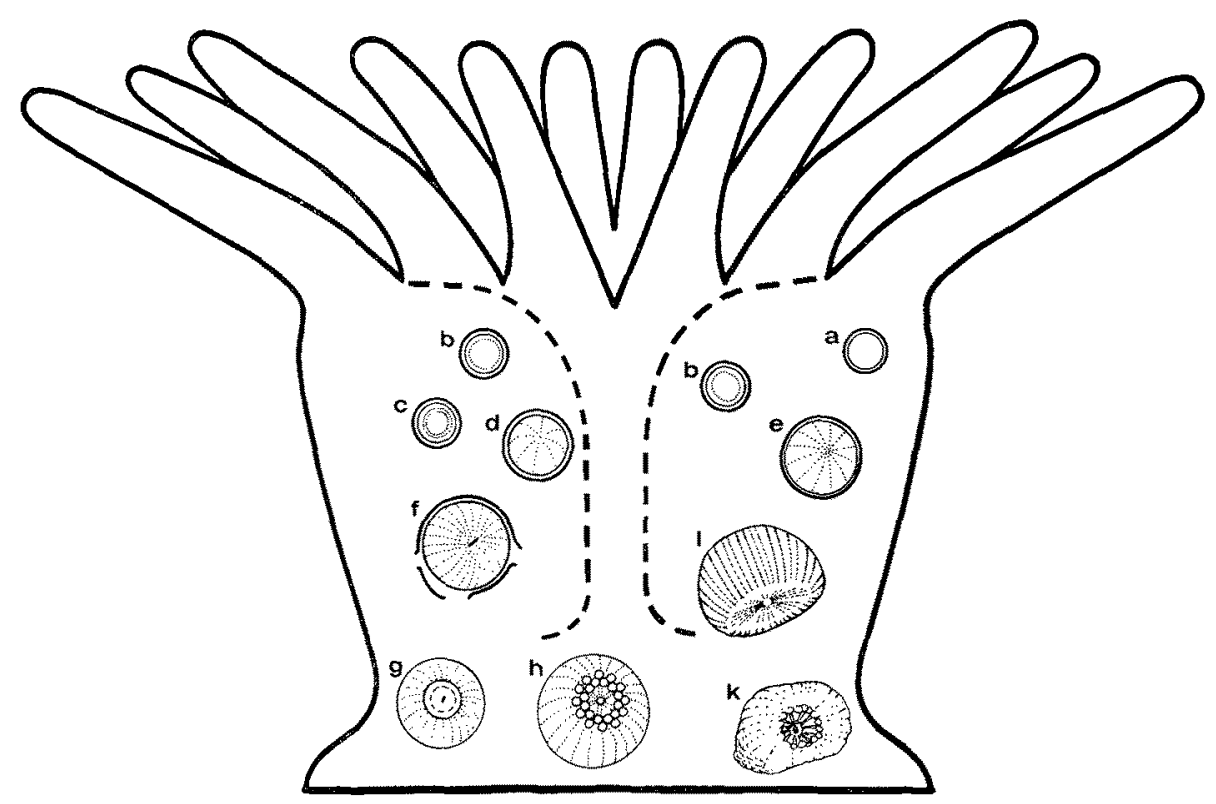

Fig. 5: Schematic synopsis of the reproduction and larval development in Actinostola spetsbergensis. $a$ fertilized egg, $b$ blastula stage, $c$ gastrula stage, $d$ hypothetical stage with 8 septa, $e$ larval stage with 12 septa, $f$ stage with 24 septa breaking embryonal envelope, $g$ larva with 24 septa showing first signs of tentacle formation, $b$ larval stage with 24 tentacles, $i$ larval stage during metamorphosis showing aboral flattening of the body, $k$ young anemone

blastoderm cells. With increasing numbers, some of these cells approach the surface, particularly in an area where the blastoderm cells seem to multiply more rapidly than elsewhere. Here, a thick-layered polar cap of blastoderm cells is formed (observed in three germs); sections of this cap show that the cells are not arranged at random, but in closely packed layers (Fig. 3B). This histological picture suggests that the endoderm is formed by a combined process of invagination and multipolar immigration. Similar conditions and aspects were found in Halcampa duodecimcirrata (see Nyнolm, 1949; p. 488, Fig. 12b). Finally, the gastrula consists of two concentric layers, still arranged below the surface of the germ. Concerning the outer appearance and size of the blastula and gastrula stage, there is no difference to the undeveloped mature egg; all these stages retain the natural orange colour of the egg yolk.

\section{Earlylarvaldevelopment}

The smallest larval stage observed measures $2.5 \mathrm{~mm}$ in diameter and possesses $8+4$ septa, which remain in a rudimentary condition, however (Fig. 4). Both ectoderm and endoderm retain a simple embryonic appearance in this early larval stage; the cells are almost cubiform with distinct nuclei and without any advanced differentiations. The centre of the larva is partly filled with diffuse yolk grains, joining the 
larval endoderm at some points. The undifferentiated structure of the larval epithelia is retained until the larva breaks the embryonic envelope; the larvae usually hatch into the gastral cavity of their mother at the 24 septa stage. Further development proceeds with histological differentiations of ectoderm and endoderm and with changes of body shape and size. The different developmental stages are demonstrated in Figure 5, which gives a schematic synopsis of the whole reproductive cycle of $A$. spetsbergensis. The first step of metamorphosis into the young anemone consists of simultaneous formation of a large number of tentacles (Fig. $5 \mathrm{~g}$ and $5 \mathrm{~h}$ ), accompanied and followed by further enlargement of the body and additional formation of septa. Finally, the aboral pole flattens (Fig. 5i) and body wall contractions result in a small anemone, with the typical wrinkled body wall of $A$. spetsbergensis (Fig. $5 \mathrm{k}$ ).

\section{DISCUSSION}

Actinostola spetsbergensis demonstrates a case of unusual economy in respects to the production of eggs. Most Actiniaria (especially those with small planktonic larvae) are crowded with eggs during the reproductive period and even in sea anemones with large yolky eggs the number of eggs is rather large (e.g. Epiactis prolifera according to DunN 1975; Bolocera tuediae, Hormathia nodosa, Actinostola groenlandica, Stomphia coccinea, Choriactis laevis according to own observations). By contrast, A. spetsbergensis develops only very few oocytes; this leads to the question as to what reproductive facilities enable this species to survive by using such a small number of eggs. In fact, most of the deviations described in reproduction and early development seem to have a share in solving this problem.

First, A. spetsbergensis seems to have the capability to produce eggs during a second reproductive period if there are suitable conditions. From the differences in egg production in the subarctic (East Atlantic) and arctic (Canadian arctic) specimen there is probably a relation between the lenght of summer season and the presence of a second reproduction period. This flexibility in egg production would signify that A. spetsbergensis is able to increase the reproductive rate in response to certain ecological factors.

There is no doubt that the elaborate and complex brood care plays the leading part in achieving successful development of the few eggs; this brood care includes not merely protection of the young but also some precautions for the developing egg. The thick-walled, double-layered and histologically highly differentiated envelope around the oocyte should be regarded as part of the brood caring mechanisms in $A$. spetsbergensis. Although there is no evidence of a nutritive function or advantage, the histological appearance together with the occurrence and fate of this special layer make it very likely that this envelope represents a follicle, providing the developing egg with nutritive substances.

At present no comparable structures are known in other sea anemones, but nutritional relations between surrounding epithelia and oocyte have been discussed since 1879, when Hertwig \& Hertwig discovered the "Fadenapparat" or "Nährapparat", a connection between septal epithelium and oocyte. This navel-like spot is 
considered to have nutritive function (Her Twig \& Hertwig, 1879; p. 551; Nyholm, 1943; pp. 102-103, pp. 194-195), although these authors assume that the surrounding endoderm is capable of storing and delivering nutritive material too, especially in those species where the "Nährapparat" is lacking (Hertwig \& Hertwig, 1879; p. 552; Nyнolm, 1943; pp. 195-196). The mesogloea may also serve as a storage tissue, as pointed out by CHAPMAN (1966; pp. 161-162), and from a morphological viewpoint SIEWING $(1969$; p. 350$)$ infers that the ovarial mesogloea has to be regarded as a follicle because of its histological properties.

In A. spetsbergensis both endoderm and mesogloea show conspicuous alterations around the oocyte compared with the common septal tissues and it may be assumed that there is not only a storage and delivering function in both layers, but that the ciliary cells support these functions by causing currents, which may be helpful for catching and carrying nutritive particles and substances. The reason for this assumption is the histological resemblance of the ciliary cells with those of the trilobate mesenteric filaments (RIEMANN-ZüRNECK, 1969; p. 218).

In sea anemones protection of young usually means that the young are retained in the gastral cavity up to more or less advanced stages. A. spetsbergensis shows a more active and effective manner of taking care of its offspring: the younger stages (from fertilized egg to 24 septa larval stage) are enclosed in an envelope with apparently adhesive properties, by means of which they are fixed in the upper part of their mother's body. Hereby the developing stages are not exposed to internal currents and sudden contractions, which can involve the risk of being prematurely ejected.

Although spiny and jelly-like egg envelopes are rather common in sea anemones (Nyholm, 1943; p. 107, 147; Nyholm, 1949; p. 481; Schmidt, 1972; p. 110; Siebert, 1974; p. 1384), sticky qualities of such envelopes have never been observed nor are they known to serve as brood caring mechanisms. The only cases where young are known to adhere to their mother (on the lower part of the column) occur in Epiactis, but only a low percentage of the young adhere and there is apparently no adhesive substance (DunN, 1975; p. 215).

The older larvae of $A$. spetsbergensis are retained in the gastral cavity in a similar way as is known from other brooding anemones. Here, the development proceeds and finally results in small anemones. These small anemones are probably extruded and settle instantly, as may be suggested from the fact that $A$. spetsbergensis is usually found closely aggregated and does not reproduce asexually. Nevertheless, it seems very likely that not all larvae finish their development inside their mother, but leave her during violent body contractions or simply because of their low specific gravity. This is confirmed by the observation that in most females with young in their gastral cavity, one or two young are found in the actinopharynx. It is imaginable that a passive release of larvae applies mainly to those females which contain a larger quantity of larvae; the release of larval stages would include dispersal advantages for this arctic species.

As a result, $A$. spetsbergensis possesses a complexity of reproductive habits and brood-caring mechanisms. Furthermore, it seems probable that this species is able to respond to certain environmental factors, which indicates adaptive flexibility. These 
results answer not only the question of how this species manages to survive in spite of an extremely small number of eggs, but it may also be the reason for the widelyranging horizontal and vertical distribution of $A$. spetsbergensis.

In my publication on the larval development $I$ stated that the giant larvae are the dispersal stages of deep-sea Actiniaria. Accordingly, A. spetsbergensis has to be regarded as originally living in deep-sea habitats (or still living there?) and retaining the typical giant larval development in more shallow environments. In these surroundings, long-living pelagic larvae appear to be unable to survive (cf. THorson, 1952; p. 295); thus, in A. spetsbergensis, the highly specialized brooding habits and mechanisms seem to avoid pelagic life of the larvae.

\section{SUMMARY}

1. Actinostola spetsbergensis Carlgren from different Atlantic and Pacific localities has been found to reproduce sexually during the arctic summer.

2. Oogenesis of the remarkably few eggs proceeds inside the conspicuous and histologically altered layers of mesogloea and endoderm.

3. The fertilized egg and all subsequent developmental stages up to the 24 septa stage are surrounded by a peculiar non-cellular envelope by means of which they adhere in the upper part of their mother's interior.

4. Cleavage is superficial and endoderm seems to be formed by combined processes of invagination and multipolar immigration.

5. The elaborate brood-care is assumed to be of special importance for achieving successful development in $A$. spetsbergensis.

6. By contrast to other brooding anemones there are special brood caring mechanisms, including particular precautions for the developing egg.

7. The reproductive and brooding particularities of $A$. spetsbergensis have adaptative significance in respect to the ecological conditions of the arctic region.

Acknowledgement. Technical assistance was gratefully received from Mr. H. Gawron, student at the University of Hamburg.

\section{LITERATURE CITED}

Beneden, E. van, 1898. Les anthozoaires de la "Plankton-Expedition". Ergebn. Atlant. Ozean Planktonexped. Humboldt-Stift. 2, 1-222.

Carlgren, O., 1893. Studien über nordische Aktinien. K. svenska VetenskAkad. Handl. 25, $1-148$.

- 1924. Die Larven der Ceriantharien, Zoantharien und Aktiniarien, mit einem Anhang zu den Zoantharien. Wiss. Ergebn. dt. Tiefsee-Exped. „Valdivia“ 19, 342-476.

- 1934. Ceriantharia, Zoantharia and Actiniaria. Rep. scient. Results Michael Sars N.Atlant. deep Sea Exped. 5, 1-52.

Chapman, G., 1966. The structure and functions of the mesogloea. Symp. zool. Soc. Lond. 16, $147-168$. 
DunN, D. F., 1975. Reproduction of the externally brooding sea anemone Epiactis prolifera VERriLl, 1869. Biol. Bull. mar. biol. Lab., Woods Hole 148, 199-218.

HerTwig, O. and R., 1879. Die Aktinien anatomisch und histologisch mit besonderer Berücksichtigung des Nervenmuskelsystems untersucht. I., Jena Z. Naturw. 13, 457-640.

Nyноцм, K. G., 1943. Zur Entwicklung und Entwicklungsbiologie der Ceriantharien und Aktinien. Zool. Bidr. Uppsala 22, 87-248.

- 1949. On the development and dispersal of athenaria actinia with special reference to Halcampa duodecimcirrata, M. SARs. Zool. Bidr. Uppsala 27, 465-506.

Rremann-Zürneck, K., 1969. Sagartia troglodytes (Anthozoa) Biologie und Morphologie einer schlickbewohnenden Aktinie. Veröff. Inst. Meeresforsch. Bremerh. 12, 169-230.

- 1976. A new type of larval development in the Actiniaria: Giant Larvae. Morphological and ecological aspects of larval development in Actinostola spetsbergensis. Conference Coelent. Ecol. Behav. Plenum, New York (in press).

Sснмірт, H., 1972. Prodromus zu einer Monographie der mediterranen Aktinien. Zoologica, Stuttg. 121, 1-146.

Siebert, A. E., 1974. A description of the embryology, larval development, and feeding of the sea anemone Anthopleura elegantissima and A. xanthogrammica. Can. J. Zool. 52, 1383 to 1388.

Thorson, G., 1952. Zur jetzigen Lage der marinen Bodentier-Okologie. Zool. Anz. (Suppl.) 16, 276-327.

Author's address: Dr. Karin RIEMANn-ZürneCK

Institut für Meeresforschung

Am Handelshafen 12

D-2850 Bremerhaven

Federal Republic of Germany 